\title{
特集にあたって \\ 地方自治体のにおい対策新展開
}

北村 清明

ここ数年の悪臭苦情は, 依然として年間約 2 万件という高い水準の件数で推移しているとともに, 飲食店 や個人住宅などを原因とするいわゆる都市型の苦情の割合が目立っている傾向にある。これに対し, 悪臭苦

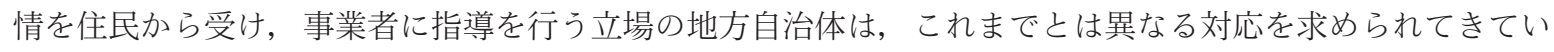
る状況にある，規制地域を拡大すべきか，臭気指数規制を導入すべきか，悪臭苦情への対応はこれまで通り でいいのか，といったことに頭を悩ませている自治体の担当者む多いと思われる。そこで今回の特集では， こういった状況に対して新たな取り組みを実施しているいくつかの事例を紹介したい.

埼玉県の山内剛宏氏之風間雄介氏には，県内市町村への悪臭防止法の臭気指数規制導入にあたっての，事 業場に㧍ける実態調査などをもとにした臭気指数規制の素案の作成, これに対して, 市町村の意向, 県民の 意見，事業者の実情を勘案して規制基準を決定したという経緯を紹介していただいた。また，その規制の内 容として，一部の市町については物質濃度規制を継続させたこと，臭気指数規制を導入した市町については 地域の実情に合わせて基準値を設定したことを紹介していただいた。

横浜市の高橋俊和氏之悪七由美子氏には, 特に飲食店からの臭気に対する苦情に対応するために「横浜市 生活環境保全等に関する条例」の規定による,「飲食店等がにおいに関して配慮すべき事項」を紹介していた だいた，飲食店が実際に対応可能な内容となっているとともに，運用にあたってはパートナーシップによる 問題解決のために行政が調整役を務めており, 施行後の解決事例も紹介していただいた。

川崎市の安藤仁氏と岩瀬義男氏には，臭気指数規制を「川崎市公害防止等生活環境の保全に関する条例」 に盛り込んだこと, その特徵として, 基本となる敷地境界基準をもとに, 時問帯別敷地境界基準, 地域別敷地 境界基準，業種・規模別敷地境界基準を加算した規制基準の設定が挙げられることを紹介していただいた。

東京都下水道局の横田義春氏には, 悪臭の排出者 (下水道管理者) としての自治体の取り組みとして, 各施 設でのマニュアルや行動計画に基づく臭気対策，自主的な臭気測定，迅速な苦情対応，新しい脱臭技術の開 発を紹介していただくとともに, ビルピット所有事業者への指導を行っていることを紹介していただいた。

以上の各原稿を読んでいただくと，各自治体とも対策を実施するにあたっては細かな検討を行っており， いかに悪臭苦情を低減して住民生活の質の向上に資するか，ということに真摰に取り組んでいるかが扮分か りいただけることと思う。一方, 事業者側にとっても負担が少ない対策で済むよう配慮している。このよう な, 悪臭の発生源である事業者の取り組みを促し, 苦情を申し立てる住民の理解を得るという, 悪臭苦情を 低減するための自治体担当者の努力や熱意は今後も欠かせないであろう。

各執筆者には, 通常業務でお忙しいところ, 快く執筆を受諾していただいたことに大变感謝しており, こ の紙面を借りて厚く御礼申し上げたい，本特集が全国の自治体の臭気対策に携わる多くの担当者に読まれ， 今後の臭気対策の参考としていただき, 臭気苦情の低減へと結びっいていくことを願ってやまない.

なお，本誌にて臭気苦情の解決事例を継続して紹介していく新特集を企画している，その他にも，協会や 本誌を通じた自治体間の情報交換がより活発になされるような企画を実施していく予定である。自治体の臭 気施策担当者の方々には是非今後の協会の取り組みにも期待していただきたい.

北村 清明（きたむら きよあき） Kiyoaki Kitamura

Evolution of policies and measures by local authority against off ensive odor

独立行政法人 土木研究所 水環境研究グループ（水質） †305-8516 茨城県つくば市南原 1-6 